\title{
The Liber de causis and the potentia sive virtus intellectiva Formula in Dante's Political Philosophy
}

\author{
Victoria Arroche \\ Universidad de Buenos Aires
}

In the Monarchia and the Convivio, Dante explains that human beings are the only entity situated between corruptibility and incorruptibility. Created as a union of soul and body, human beings are, in fact, endowed with a dual nature. With respect to the human condition, i.e. their bipartite essence, each person may be conceived of as both perishable and, on the count of the soul, not perishable, at the same time. ${ }^{1}$ Parting from this dual nature, the Italian poet establishes how humanity as a whole could achieve its proper and distinctive end: earthly happiness. This ethical aim hinges on a specific and higher capacity, which Dante describes as a potentia or virtus intellectiva. In fact, humanity as a whole could achieve its end by exercising its proper function, which is to actualize the potentia intellectiva entirely, simultaneously, and continually (actuetur vis ultima tota simul semper). ${ }^{2}$ According to him, this would be possible if humanity correctly ordered temporal affairs under a sole Monarch. And this is, clearly, the political aspect of Dante's thought. Dante presupposes a particular connection between the people and the government-one that differs from other social interrelations.

The subject of this study is to analyze some of the passages of Dante's political work in the Convivio and the Monarchia, taking detailed account of the notions of potentia and virtus and the way they operate in these political treatises. Because the author uses the ultima potentia formula to characterize the specific human virtus, and because this formula also appears in the Liber de causis, I will consider how this anonymous text was received in the Latin West and influenced the rise of political theories in the Middle Ages. In fact, I believe that Dante's quotations of the Liber resulted from new philosophical and metaphysical instruments that allowed him to construct a rational argument and

1 Cfr. Monarchia L. III, c. 15, 3-6; Convivio L. III, c. 7, 5 and L. IV, c. 21, 4-6.

2 For the formula tota simul cfr. Monarchia L. I, c. 3, 8-10 and in Monarchia L. I, c. 4, 1-2 the expression semper is used. 
thus to develop his political thought. ${ }^{3}$ In this respect, the meaning and connotation of the concepts of potentia and virtus must be clarified. This is so because, on the one hand, these concepts signify an intellectual capacity or strength which is distinctive of human beings. Dante claims that there is a proper capacity of the human soul intended as an immanent strength, therefore, there is a connection with the rise of political theory in the Middle Ages. Certainly, as politics would ultimately concern the development of a specific human capacity, Dante's claim is part of the construction of a "new" scientific field, the object of which are temporal and human matters. On the other hand, Dante's use of these concepts expresses the potentia or virtus as a power that flows through the gradual structure of reality formed by primary and secondary causes. In this sense, the idea of potentiality and its metaphysical richness seems to be the theoretical support of a political application in the temporal and human field. In fact, under the Neoplatonic philosophical tradition, represented by Proclus and the Liber de causis, causes are conceived of as substances that have the capacity to shape reality and to trickle their power or strength down to the lower levels of reality.

As previously mentioned, the notion of potentiality in Dante's political works signifies a capacity or strength that represents human perfection. Thus, it has active meaning because it indicates the exercise of a specific capacity. In this

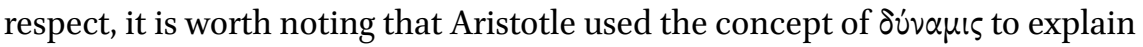
the state of a substance that is not actuality, i.e. a state which has not reached its perfection. To become what it really is, it needs the agency of a substance, which is already actuality. Therefore, according to Aristotle, the perfection of a substance is connected to its actualization. ${ }^{4}$ On the contrary, according to Proclus' Elements of Theology, the potentiality of a substance is a power; thus, it is a capacity and a perfection. Proclus reversed Aristotle's doctrine because, in his view, the related concepts are potentiality and perfection. ${ }^{5}$ As this last meaning

3 Cfr. Monarchia L. I, c. 3, 1-3 where the concept of inquisitio describes an investigation based on rational principles.

4 Proclus reworked Aristotle's distinction between an active and passive potentiality. Cfr. Metaphysics IX 1046a 5, 10-15: "We have made it plain elsewhere that 'potentiality' and 'can' have several senses [...] One kind of potentiality is the power of being affected; the principle in the patient itself which initiates a passive change in it by the action of some other thing, or of itself qua other. Another is a positive state of impassivity in respect of deterioration or destruction by something else or by itself qua something else [...]." (all English translations are mine, unless otherwise stated) Cfr. also Aristotle, Metaphysics v 1019a. See Gersh 1978, p. $27-45$.

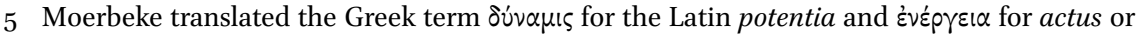
operatio. He chose the word perfectio for the Proclean expression $\tau \dot{0} \tau \varepsilon \dot{\lambda} \lambda \varepsilon 10 v$ which is clearly 
of potentiality subsists in the Liber de causis, which is a source of Dante's political work, the notions of potentia or virtus in his political theory is one, albeit indirect, reception of Proclus' heritage in the 13th and 14th centuries.

\section{Potentia sive virtus intellectiva as an Ultimate Capacity of the Human Soul in the Convivio and the Monarchia}

During the second half of the 2oth century, scholars debated the impact of the Aristotelian concept of nature on the development of political thought in the Late Middle Ages. Some medieval scholars deemed the reception of Aristotle's philosophical work as the main and practically sole reason for the production of political textbooks in the West between the 13th and 14th centuries. Others, instead, noted that there was a previous philosophical ground on which Aristotle's texts were received. Thus, according to them, the influence of different philosophical traditions must be taken into account, such as Neoplatonism or Ciceronian thought, in the rise of Politics as a science. ${ }^{6}$ Still, it was widely assumed that political thought in the Middle Ages parts from new considerations of human nature that are offered by an anthropological model that puts forth a particular metaphysics of the soul and the human mind. To be precise, according to Dante, humanity can be differentiated from other species by means of an intellectual capacity or strength. Since the expression potentia sive virtus intellectiva concerns an essential characteristic of human nature, even if

related to the Aristotle's notion of entelechy. Since Proclus conceived the capacity to produce or cause an effect in connection with the potentiality of a substance, the schema acquires the following gradual structure: the first principle possesses a perfect and complete potentiality (plenum et perfectum) and produces by superfluity or surplus of potentiality. The Henads are characterized as autopotentia and that means that their power coincides with their actuality or perfection. Their action takes place from themselves to themselves and they don't need to act on a substrate (causa causatum). Next, following that grade, there are different groups or totalities that may be caused by a) causes anterior or preexisting to the parts of a substance (ante partes), b) causes that exist simultaneously in all the substance's parts (ex partibus) or c) causes that exist in each part of the substance (in parte). Cfr. Boese 1987. Dodds speaks of "superfluity of potency," cfr. Dodds 1963, p. 31. Also Gersh 1978, p. 50-51. For the formula "sovrabbondanza di potenza," cfr. D'Ancona 1986, p. 23.

6 A description of the debate in Bertelloni, Francisco 200o, p. 9-39. Walter Ullmann argued for Aristotle's libri morales as the principal explanation of the rise of politics during the $13^{\text {th }}$ and 14th centuries in the West. Cfr. Ullmann 1961. On the contrary, Cary Nederman emphasized the role of the Ciceronian philosophical tradition. Cfr. Nederman 1996, p. 563-585. On p. 571 he claimed that the use of Aristotelianism was as a language and not as a doctrine and quoted Black 1992. See also Nederman 1991, p. 179-195, particularly p. 179 where he discussed Ullmann's, Kristeller's and Wilks' considerations. Cfr. also Nederman 1988, p. 3-26. 
the concept of nature refers to a physical domain, it also denotes a specific and immutable essence that operates and gravitates toward its own proper good. In fact, in Dante's political work that operation is possible because an "ultimate capacity" exists. In the Monarchia, Book I, chapter 3 , the Italian poet says:

Que autem sit illa [operatio], manifestum fiet si ultimum de potentia totius humanitatis appareat. ${ }^{7}$

The distinctive capacity that may be exercised by humanity entirely, simultaneously and continually, is an intellectual strength:

Patet igitur quod ultimum de potentia ipsius humanitatis est potentia sive virtus intellectiva. ${ }^{8}$

In the second chapter, third treatise of the Convivio, Dante also asserts that the "place" of the potenza ultima is the human soul; thus, he is clearly speaking about a rational capacity:

E quella anima che tutte queste potenze comprende, e perfettissima di tutte l'altre, è l'anima umana, la quale con la nobilitade de la potenza ultima, cioè ragione, participa de la divina natura a guisa di sempiterna intelligenzia. ${ }^{9}$

On the one hand, some of the translations of the ultimum de potentia formula refer to a specific capacity. For example, the word ultimum, in relation to an "intellectual potentiality," was translated by Vinay from Latin into Italian as specifica and Bertelloni translated the term into Spanish as propia. In English, Aurelia Henry uses the expression distinctive in her 1904 translation, and more recently Richard Kay used the term highest in his version. ${ }^{10}$ Both Vinay and

$7 \quad$ Monarchia L. I, c. 3, 4-5: "What this function is, will be evident if we point out the distinctive capacity of humanity as a whole." Richard Kay translates ultimum de potentia as "highest power." (transl. Henry) See infra, footnote 11.

8 Monarchia L. I, c. 3, 6-7: "It is evident, therefore, that the differentiating characteristic of humanity is a distinctive capacity or power of intellect." (transl. Henry) Cfr. also Monarchia I, 3, 8-9; Monarchia, I, 4, 1-2.

9 Convivio III, c. 2: "The soul that comprehends all these powers, and the one that is the most perfect of them all, is the human soul, which by the nobility of its highest power (that is, reason) participates in the divine nature as an everlasting intelligence." (transl. Lansing) 
Bertelloni's translations of potentia indicate that it is an active function of the human mind. For his part, Vinay translated potentia into Italian as capacità and Bertelloni chose operación for the Spanish version. Like scholars from Italy and Argentina, A. Henry and R. Kay also stressed the active sense of the notion of potentia, the former translating it as capacity and the latter as power. On the other hand, Pier Giorgio Ricci, who published the critical edition of the Monarchia, remained silent regarding the term ultimum in connection with potentia. Nevertheless, he certainly provided remarks for the concept of fine ultimo that appears in the Monarchia I, 3 just before the ultimum de potentia formula. In fact, he explains that fine ultimo means "a maximum good". Vianello equally proposed a translation that emphasizes the same aspects of the words ultimum and potentia, indicating that their meaning is l'estremo limite della potenza dell'umanità stessa, which points to the idea of maximum or superior. Furthermore, Vianello justified his translation with a quote from Albert the Great's De celo et mundo on the meaning of the term virtus. Additionally, Albert's definition of virtus is noteworthy in that it includes the expressions ultimum and potentia:

Si ergo volumus diffinire virtutem, cum sciamus virtutem consistere in ultimo et maximo, ad quod se extendit virtus activa, dicemus, quod virtus est ultimum, quod est in re potente de potentia sua activa, sicut ultimum potentiae fortitudinis Herculis diximus esse vincere triginta. Quantitas ergo potentiae extensa ad triginta erit virtus Herculis. ${ }^{11}$

Virtus as the ultimate limit of the capacity or strength of an entity can surely be connected to those passages of the Monarchia and the Convivio in which Dante used the notions of potentia, virtus and ultimum to express the intellectual capacity that has to be exercised by humanity as a totalitas. Indeed, Dante equates the concepts of potentia and virtus (potentia sive virtus) because he can define potentia as an active power, which is the proper capacity of

I, c. 3. Translations: Vinay 1950; Bertelloni 1984; Ricci 1965; Vianello 1921; Henry 1904; Kay 1998. Kay's version offers other possible English translations and meanings of the formula ultimum de potentia on p. 14, n. 10.

11 Albert the Great, De caelo et mundo, I, tr. 4, c. 5, p. 88: “Thus, if we wish to define 'virtue', knowing that it consists of the ultimate and highest peak an active potentiality can reach, we would say that, like active potentiality, virtue is the ultimate limit of a thing's capacity. As we have said, the ultimate limit of the capacity of Hercules' strength is to defeat thirty men. Consequently, Hercules' virtue is the quantity of potency extended to defeating thirty men." 
human beings and which can shape reality. ${ }^{12}$ In addition, since that capacity is ultimum, it represents the ultimate limit of the human mind.

Although the author of the Liber de causis redefined some crucial ideas from his Proclean source Stoikheiosis theologiké, the anonymous treatise holds that an indivisible and eternal substance must possess an active potentiality, meaning a certain capacity or power to produce an effect. ${ }^{13}$ As stated in proposition $\mathrm{v}(\mathrm{VI}), 64-65$ of the Liber de causis, Intelligence is an indivisible and immutable substance. ${ }^{14}$ In proposition IV, 37 the author also affirms that the first of things created is being; and then he holds that all that follows the First Cause is intelligentia, completa et ultima in potentia et reliquis bonitatibus. ${ }^{15}$ The First Cause is, strictly speaking, the only hypostasis that can create (by modus creationis) and Intelligence is the first thing that is created. ${ }^{16}$ The author of the treatise establishes that the latter obtains its esse from the former, meaning that it depends ontologically on the First Cause. In that sense, Intelligence is determined by a limit, which is its form, ${ }^{17}$ but it is also self-sufficient in relation to its capacity or productive strength, that is, its potentia or virtus. In the Liber de causis, Intelligence is considered as ultima potentia because it is sufficiens per se ipsam..$^{18}$

12 Moerbeke expressed the idea of a virtus factiva in his translation of the Stoikheíosis theologiké, Cfr. prop. 7: Si autem ipsum productivuum est potentie omnis ei quod post ipsum, et si se ipso possit facere tale quale illud: si autem hoc, et facere utique se ipsum potentius. Neque enim id quod est non posse prohibet, presente factiva virtute. Cfr. Boese 1987, prop. 7 .

13 This term can be found in the Liber de causis from proposition I, 14 with the verb efficit. The term always implies an action, an operation or an influence upon an effect. Specifically, from proposition III and on, the expression efficiens is always related to the idea of a productive capacity. The virtus efficiens formula is in proposition XII (XIII), 121. Cfr. Pattin 1966. Recent philological and historical findings as well as important philosophical analyses in Calma 2016, p. 11-51.

14 Liber de causis, prop. VI (VII), 64: Intelligence is an indivisible substance. 65: This is because if it is without magnitude and is not a body and does not move, then without doubt it is indivisible.

15 Liber de causis, prop. IV (43): "Intelligence, complete and ultimate in power and the other perfections". (transl. Brand)

16 Propositions in which Intelligence is identified with the first of the things created: Prop. $\mathrm{XV}(130)$ ens primum creatum, scilicet intelligentia. See also prop. VI (70) and prop. XXII (173).

17 Cfr. Liber de causis, prop. viII (9o).

18 Liber de causis, prop. XXI (167). See also prop. XIV (124-128). The potentiality of Intelligence (as the other perfections) comes from the First Cause but its operation, that is its capacity for causing, belongs to Intelligence properly. 
Therefore, it constitutes a superior principle of a range of effects that descend from the more universal to the more particular. The author of the Liber de causis also claims that Intelligence is the complete / perfect reality apud nos $;{ }^{19}$ and, because of its similarity with the First Cause, it is also described as a prince. This hypostasis, indeed, operates as an intermediary because it connects two spheres: on one side, that which contains things that are inferior to Intelligence and, on the other side, the First Cause:

Intelligentia est princeps rerum quae sunt sub ea et retinens eas et regens eas, sicut natura regit res quae sunt sub ea per virtutem intelligentiae. Et similiter intelligentia regit naturam per virtutem divinam. ${ }^{20}$

Like its Proclean source, the propositions of the Liber de causis do not simply represent a logical sequence, but also stand for an ontological order that is gradually structured. Through the expression ultimum de potentia, Dante indicates a superior capacity of the soul. ${ }^{21}$ In the Convivio III, he quotes the Liber de causis to explain the ontological hierarchy not only in respect to universe, but also in connection with the human soul:

E però che nel'ordine intellettuale de l'universo si sale e discende per gradi quasi continui da la infima forma a l'altissima [e da l'altissima] a la infima, sì come vedemo nel'ordine sensibile. [...] $\mathrm{E}$ avvegna che posti siano qui gradi generali [i.e. related to the order of reality], non dimeno si possono porre gradi singulari; cioè che quella [i.e. Divine Goodness / the influence of the First Cause] riceve, de l'anime umane, altrimenti una che un' altra. ${ }^{22}$

As Dante expressed in the Convivio, even if God, i.e. an absolute simple principle, influences the whole of creation, not all things created can receive His

19 Liber de causis, prop. XxI (167).

$20 \quad$ Liber de causis, prop. viII (82): "Therefore, Intelligence is the sovereign over the things that are under it; and it maintains them and governs them, just as Nature governs the things that are under it by virtue of the power of Intelligence. And similarly, Intelligence governs Nature by virtue of the divine power." (transl. Brand)

21 The rational capacity which is superior to the vegetative and sensitive potencies.

22 Convivio III, cap. 7: "Although only the general gradations are set down here, we could nevertheless set down the particular gradations: that is, that among human souls one receives goodness differently from another. And, because in the intellectual order of the universe, one ascends and descends throught continuous gradations from the lowest form to the highest and from the highest to the lowest, as it happens in the sensible order". (transl. Lansing) Cfr. also Nardi 1949, p. 187-188; Raffi 2004, p. 30-48. 
goodness equally. In other words, even if the First Cause created the totality of humanity with a unique influx, each entity receives that influence according to its modus suae potentiae. That is the formula that the author of the Liber de causis uses to explain the existing diversity with respect to the capacity or strength of different entities.

\section{From the Capacity or Strength of the Human Soul to the Power of the Monarchy}

I've attempted to present the functionality of the concepts of potentia and virtus according to what may be called "the metaphysics of the human soul and mind". These notions express, in Dante's works, the highest peak that the capacity or strength of the human intellect can reach. To do so is to achieve humanity's proper end, that is, to actualize the potentiality of the human race. In this sense, it is clear that politics, intended as a specific relation between the community and the Monarch — who guides humanity toward the achievement of that end-stems from the exercise of that intellectual capacity.

To further develop this political aspect of the notion of potentiality, two concepts are worth noting in Books I and III of the Monarchia. Those concepts are ordinatio and reductio. Dante uses them to describe some specific modes of causality. On the one hand, since the Monarch "is the most universal cause of men living well", ${ }^{23}$ the idea of ordinatio in Book I indicates that there exists an alignment of the effects towards the cause ratione finis. This order of gradation results from the capacity or strength of the effect, that is, its modus potentiae. On the other hand, the idea of reductio, developed in Book III, shows that the emperor's authority depends directly on God, who, strictly speaking, is the only cause that can create. As we have seen in the passage of the Convivio III, Dante describes the gradual ontological order of reality. This overview may also illuminate the passage of Book I, chapter 11 of the Monarchia in which the distance that the Monarch and the other princes keep from subjects differs:

Sed homines propinquius Monarche sunt quam aliis principibus [...] principibus aliis homines non appropinquant nisi in parte, Monarche vero secundum totum. Et rursus: principibus aliis appropinquant per Monarcham et non e converso. ${ }^{24}$

23 Monarchia, L. I, c. 11, 18.

24 Monarchia, L. I, c. 11, 15-17: "Men are closer to the Monarch than they are to other princes [...] men are closer to other princes in part, but to the monarch in full. And again, men approach other princes through the Monarch, and not conversely." (transl. Henry) 
In the Monarchia, the idea of proximity shows the real distance between the grades of an ordered reality. To function, causation requires, as an essential characteristic of the system, this stated distance between causes and effects because that also concerns the higher or lesser similarity between them. In addition, according to this Neoplatonic model of causality, the universality of a cause implies a greater capacity for generating effects.

In Book I, chapter 11, Dante quotes the Liber de causis to provide a metaphysical legitimation of a political order in which the emperor is identified with a First Cause that acts in the realm of time:

Quanto causa est universalior, tanto magis habet rationem cause, quia inferior non est causa nisi per superiores, ut patet ex hiis que De causis [...] Cum ergo Monarca sit universalissima causa inter mortalis ut homines bene vivant quia principes alii per illum, ut dictum est, consequens est quod bonum hominum ab eo maxime diligatur. ${ }^{25}$

The ontological support of the political bond between the princes and the people is based on the existence of the Monarch, who is characterized as a First Cause in the domain of temporal and human matters. Therefore, according to Dante, the monarchy may be conceive as an autonomous political institution. ${ }^{26}$ Certainly, it is not a a sum of individualities as a progression from the smaller communities towards the empire. ${ }^{27}$ On the contrary, it is the monarchy that orders all the levels of reality to the ultimate end and assures the causal connection between intermediaries and effects. To be precise, if somehow people's well-being depends on princes, it is because the emperor transmits to them his potentia or virtus, that is to say, that the power and the authority of princes derives from the Monarch's capacity and strength.

Et sic per prius et inmediate Monarche inest cura de omnibus, aliis autem principibus per Monarcham, eo quod cura ipsorum a cura illa suprema descendit. $^{28}$

25 Monarchia L. I, 11, 17-18: "Moreover, the more universal thecause, the more it possess the nature of a cause, for the lower cause is so merely by virtue of the higher, as can be inferred from the treatise on Causes [...]. As we have said, other princes are causes merely by virtue of the Monarch; then, among mortals, he is the most universal cause of man's well-being, and it is he who loves mankind's well-being above all others." (transl. Henry)

26 Cfr. Liber de causis, prop. XXI (167) the concept is sufficiens per se ipsam.

27 Empire and Monarchy are synonyms. Cfr. Monarchia L. I, 2, 3: Est ergo temporalis Monarchia, quam dicunt Imperium.

28 Cfr. Monarchia, L. I, 11, 16-17: "Thus the Monarch is the direct and primary guardian of it 
The quote from Liber de causis in chapter 11 clearly indicates that the causal model is taken from proposition 1 of the anonymous treatise. Dante assigns to God the characteristics of the remote cause and to the Monarch those of the proximate cause. Thus, he argues in favor of an ontological distance. In that way, he can articulate his argument showing the similarity between humankind and God if the former is united as whole, that is, if monarchy exists to govern on temporal matters, so that the Monarch can guide the people to their proper end.

Et omne illud bene se habet et optime quod se habet secundum intentionem primi agentis, qui Deus est [...] De intentione Dei est ut omne causatum divinam similitudinem representet in quantum propria natura recipere potest [...] Ergo humanum genus bene se habet et optime quando secundum quod potest Deo assimilatur. Sed genus humanum maxime Deo assimilatur quando maxime est unum, vera enim ratio unius in solo illo est. ${ }^{29}$

The order ratione finis grounded on the Monarchy is necessarily also the starting point of reality. This is so because the Emperor-who is one-constitutes the cause of humanity's unity inasmuch as the latter resembles the former. Indeed, Dante claims that:

Genus humanum maxime est unum quando totum unitur in uno, quod esse non potest nisi quando uni principi totaliter subiacet. ${ }^{30}$

Thus, similarity, unity and proximity render the theoretical support for Dante's political position, that is, that humanity may be ordered to unity, converting

all, while the other princes operate through him because the monarch's supreme interest descends through them." (transl. Henry)

29 Monarchia L. I, c. 8, 1-4: "And everything is well, nay, best disposed which acts in accordance with the intention of the first agent, who is God. [...] It is of the intention of God that all things should represent the divine likeness insofar as their peculiar nature is able to recieve it. The human race, therefore, is ordered well, nay is ordered for the best, when according to the utmost of its power it becomes like unto God. But the human race is most like unto God when it is most one, for the principle of unity dwells in Him alone." (transl. Henry)

30 Monarchia L. I, 8, 4-5: "The human race is most one when all are united together, a state which is manifestly impossible unless humanity as a whole becomes subject to one Prince [and consequently comes most into accordance with that divine intention which we showed at the beginning of this chapter is the good]." (transl. Henry) 
towards a totalitas, to attain its distinctive end. That is only attainable with the Monarch as guide. ${ }^{31}$ God is a remote cause of humanity considered as a whole, because he created it directly, endows it with being (esse), and governs it through the Monarch who received its authority from Him inmediate. ${ }^{32}$ In that way, the causal chain in the temporal sphere begins with the Monarch. The Monarch is a cause possessing a kind of autonomy to exercise his own function (operatio), for he receives that capacity or strength (virtus) by the influence of the First Cause directly. Therefore, he governs that which is beneath him. Indeed, certain propositions of the Liber de causis stress the function of Intelligence as an intermediary between God and what follows Intelligence.

At this point, there is another aspect that concerns the political projection of the potentia sive virtus intellective formula. All the argumentation of the first Book of the Monarchia concerns an active aspect of intellectual capacity or strength. Consequently, it allows Dante to pass over the fallen nature of humanity and avoid the use of the ratione peccati formula to legitimate the monarchy's existence. ${ }^{33}$ Certainly, for Dante, the potentia intellectiva is the maximum of an intrinsic capacity. It is distinctive of human nature and conformed to attain earthly happiness, understood as the perfection of men in temporal life. Thus, the need of the Monarchy or Empire is clearly not justified by the infirmitas of human nature.

Nevertheless, in the third Book of the Monarchia, Dante endorsed the ratione peccati in the allegory of the sun and the moon, a well-known argument used also by the defenders of the papal supremacy over the temporal government. According to this allegory, the two celestial bodies represent two different powers, the temporal and the spiritual. The correct interpretation of the allegory is that, just as the moon receives its light from the sun, so also the tem-

$31 \quad$ According to "political Augustinianism" the temporal government is legitimated on an anthropological view that considers human nature as fallen (genus origine depravata, velut radice corrupta). According to Dante, the emergence of the Monarchy is not due to the fallen nature of the human being. Instead, Monarchy is the institution that allows humanity to reach its proper end (beatitudo) because it is the condition for the development of the ultima potentia tota, simul, semper. For "political Augustinianism" see Arquillière 1934.

32 Dante poses the problem at the beginning of Book I: Monarchia L. I, 2, 3-4: tria dubitata queruntur [...] tertio an auctoritas Monarche dependeat a Deo inmediate vel ab alio, Dei ministro seu vicario and he gives an answer in Monarchia L. III, 15, 15-16: Sic ergo patet quod auctoritas temporalis Monarche sine ullo medio in ipsum de Fonte universalis auctoritatis descendit.

33 Cfr. Augustine, Contra Iulianum L. III, 12. 24: Natura vero humana secundum catholicam fidem bona instituta, sed vitiata peccato meritoque damnata est. L. IV, 2.11 Sic virtus in infirmitate perficitur: quia et pugnare infirmitatis est. 
poral government obtains its authority from the spiritual. To refute this interpretation, Dante held that the Church and the Empire are two remedia contra infirmitatem peccati. ${ }^{34}$ However, his understanding has an opposite starting point. As Dante explains regarding the moon:

Dico ergo quod licet luna non habeat lucem abundanter nisi ut a sole recipit, non propter hoc sequitur quod ipsa luna sit a sole. Unde sciendum quod aliud est esse ipsius lune, aliud virtus eius, et aliud operari. Quantum est ad esse, nullo modo luna dependet a sole, necetiam quantum ad virtutem, nec quantum ad operationem simpliciter. ${ }^{35}$

However, the moon does not depend on the sun for its being (esse) or its capacity (virtus). Nor does it depend absolutely on the sun for its operation because the cause of its movement and the influence that it exercises over things belong to it properly. Dante replaces the moon and the sun with the temporal and spiritual rulers and establishes that:

Sic ergo dico quod regnum temporale non recipit esse a spirituali, nec virtutem que est eius auctoritas, nec etiam operationem simpliciter. ${ }^{36}$

Temporal power, indeed, does not receive its being and authority from spiritual power but instead obtains it directly from God, i.e. without intermediaries. In fact, according to Dante, the expression virtus applies to the temporal government and to the Monarch's auctoritas. Hence, it refers to the power or capacity of the Monarch to act independently or autonomously from the authority of the spiritual ruler.

In short, Dante's ratione peccati argument does not affirm an intrinsic corruption of human nature which would entail a reductio of one power into another, that is, a subordination of the temporal government to the spiritual.

34 Cfr. Monarchia L. III, c. 4, 14-15.

35 Monarchia L. III, 4, 18-19: "I say, then, that although the Moon may have abundant light only as she receives it from the Sun, it does not follow on that account that the Moon herself owes her existence to the Sun. It must be recognized that the essence of the Moon, her strength, and her function are not one and the same. Neither in her essence, her strength, nor her function taken absolutely, does the Moon owe her existence to the sun, [for her movement is impelled by her own motor and her influence by her own rays]." (transl. Henry)

36 Monarchia L. III, 4, 20-21: "In like manner, I say, the temporal power receives from the spiritual neither its existence, nor its strength, which is its authority, nor even its function taken absolutely." (transl. Henry) 
On the contrary, the argument instead relies on the fact that both powers are created by God and, consequently, have proper authority and a distinctive end from each other.

\section{Some Conclusions}

In connection with the potentia sive virtus intellectiva formula used by Dante in his political treatises, several remarks are in order. First, in Book I, these notions are employed to affirm the entity of temporal government as it is based on the existence of an ultimate end. This end can be reached by exercising a distinctive capacity or strength. This capacity or strength, though unique to each individual human being, has to be actualized by humanity as a whole. That is only possible under the guidance of the Monarch.

Second, in Book III, these concepts enabled Dante to use philosophical arguments to defend the autonomy of the temporal government in relation to the spiritual. In other words, it enabled him to stand for a relative independence of the monarchy regarding the papacy. Thus, I sustain that the indirect influence of Proclean philosophy through the Liber de causis is manifested in some parts of Dante's political work that may be assigned to the relations between cause and effects as they are established under the Neoplatonic model. Notably: a) that the ontological order has a gradual structure according to which reality proceeds from the absolute simple towards the complex and returns through the same instances or levels; b) given this order between those instances, named causes and effects, there is an ontological distance that allows a greater or lesser similarity of the effect to its cause; c) on the basis of that distance, it is also possible to describe reality in terms of remote or proximate causes; d) participation by similarity and ontological distance are concepts also related to the capacity of a cause (potentia or virtus factiva).

In addition, according to the author of the Liber de causis, the concept of potency acquires a particular meaning when applied to Intelligence. In fact, in that text, it is described as ultima potentia, expressing its condition as an intermediary between the First Cause and the created order as well as its relative autonomy and consequently its causal capacity or power in the temporal realm.

In light of Dante's Convivio and Monarchia, the potentia sive virtus intellectiva formula indicates human perfection as the ultimate limit of the intellectual capacity of the soul. Thus, humanity can be differentiated from other creatures by its nature.

Likewise, I have attempted to examine how the causal model from the Liber de causis applies to Dante's political treatises. This is evident in the identifica- 
tion of God with the First Cause (which is also conceived of as a paradigmatic cause) that creates all entities and preserves them in a state of being. Because humanity is created directly by God, the Monarchy occupies an intermediate space between the First Cause and humanity. Therefore, the Monarch may play the role of Intelligence, since his function is to rule over the things that are beneath him. It is in this respect that Dante describes the Emperor as the universal cause of the right political order. When humanity is guided by the Monarch and becomes a united whole, it may resemble its cause, which is God.

The notions of potentia and virtus apply to the constitution of the human soul's nature. Thus, they form the basis of Dante's argument to construct and consolidate the identity of temporal government in Book I. In Book III, these concepts affirm a relative autonomy of monarchy as a political institution in relation to the authority and power of the papacy.

\section{Bibliography}

\section{Primary Sources}

Albert the Great, De caelo et mundo, ed. P. Hossfeld, Opera omnia, ed. Colon. v/1, Münster, Aschendorff, 1971.

Aristotle, Metafísica, translation by V. García Yebra, Madrid, Gredos, 1998.

Dante Alighieri, Il Trattato della Monarchia di Dante Alighieri, ed. N. Vianello, Genova, Stabilimento Grafico Editoriale, 1921.

Dante Alighieri, Monarchia, ed. G. Vinay, Firenze, Sansoni, 1950.

Dante Alighieri, De Monarchia, ed. P.G. Ricci, Verona, Mondadori, 1965.

Dante Alighieri, Dante. De la Monarquía y otros textos. Estudio preliminar y selección, ed. F. Bertelloni, Buenos Aires, Centro Editor de América Latina, 1984.

Dante Alighieri, The Monarchia of Dante Alighieri, ed. A. Henry, Boston / New York, Houghton / Miflin and Company, 1904.

Dante Alighieri, Dante's Monarchia, ed. R. Kay, Toronto, Ed. Pontifical Institute of Medieval Studies, 1998.

Dante Alighieri, Convivio, ed. G. Inglese, Milano, Ed. BUR, 2004.

Dante Alighieri, Il Convivio (The Banquet), ed. R.H. Lansing, Digital Dante, Garland Library of Medieval Literature, 199o.

Liber de causis, A. Pattin, "Le Liber de causis. Édition établie à l' aide de go manuscritsavec introduction et notes", in Tijdschrift voor Filosofie 28 (1966), p. 9o-203.English translation by D.J. Brand, Wisconsin, Marquette University Press, 1984.

Proclus, The Elements of Theology, ed. E.R. Dodds, Oxford University Press, 1963.

Proclus, Elementatio theologica, translata a Guillelmo de Morbecca, ed. H. Boese, Leuven, University Press, 1987. 
Thomas Aquinas, Commento al Libro delle cause, translation by C. D'Ancona Costa, Milano, Rusconi, 1986.

\section{Secondary Sources}

Arquillière, H.-X. (1934), L'augustinisme politique: essai sur la formation des théories politiques du Moyen-Âge, Paris, Vrin.

Bertelloni, F. (2000), "La tradición prearistotélica y la formación de la política como teoría a partir de 1265", in Tópicos 18, p. 9-39.

Black, A., (1992), Political thought in Europe, 1250-1450, Cambridge, Cambridge University Press.

Calma, D. (2016), Neoplatonism in the Middle Ages. Vol. I. New Commentaries on Liber de causis (ca. 1250-1350). Vol. II. New Commentaries on Liber de causis and Elementatio theologica (ca. 1350-1500), Turnhout, Brepols.

Gersh, S. (1978), From Iamblichus to Eriugena. An investigation of the Prehistory and Evolution of the pseudo-Dyonisian Tradition, Leiden, Brill.

Nardi, B. (1949), "La conoscenza umana", in Id., Dante e la Cultura Medievale, Bari, Ed. Laterza.

Nederman, C. (1996), "The Meaning of Aristotelianism in Medieval Moral and Political Thought", in Journal of the History of Ideas 57/4, p. 563-585.

Nederman, C. (1988), "Nature, Sin and the Origins of Society: The Ciceronian Tradition in the Medieval Political Thought", in Journal of the History of Ideas 49/1, p. 3-26.

Nederman, C. (1991), "Aristotelianism and the Origins of 'Political Science' in the Twelfth Century", in Journal of the History of Ideas 52/2, p. 179-194.

Raffi, A. (2004), "Variazioni gnoseologiche sul tema della fantasia", in Id., La gloria del volgare. Ontologia e semiotica in Dante dal Convivio al De volgare eloquentia, Catanzaro, Rubbettino.

Ullmann W. (1961), Principles of Government and Politics in the Middle Ages, London, Methuen and Co. Ltd. 